Journal of Animal and Veterinary Advances 10 (5): 651-655, 2011

ISSN: $1680-5593$

(C) Medwell Journals, 2011

\title{
Association of 5-Flanking Region of Pit-1 Gene Polymorphisms with Growth Traits in Goose
}

\author{
Wen-Ming Zhao, Rong-Xue Zhao, Na Qiao, Qi Xu, Zheng-Yang Huang, \\ Yang Zhang, Xiu Li and Guo-Hong Chen \\ College of Animal Science and Technology, Yangzhou University, \\ 225009 Yangzhou, China
}

\begin{abstract}
The aim of the present study was to detect Single Nucleotide Polymorphism (SNP) in some areas of Pit-1 gene of goose to find genetic marker influencing on growth and carcass trait. The Single Nucleotide Polymorphism (SNP) of Pit-1 gene promoter was investigated in Wanxi geese. The primers for promoter in Pit-1 gene were designed according to the Pit-1 gene promoter of goose and the SNPs were detected by PCR-SSCP method. The results showed that only C-930T was detected for SNP and two genotypes (CC and TT) were found, respectively. The analysis of least square on genotypes and groups showed that there were significant differences $(p<0.01)$ on body weight of different weeks in different groups and genotypes, however, there were no differences $(\mathrm{p}>0.05)$ on body weight of different weeks in genotype-group interaction effect, then, comparison of bodyweight in different groups show that the average body weight of wanxi white goose was the largest, the average body weight of taihu goose was larger than zi goose. Variance analysis on genotype suggested that the average body weight of CC genotype and TT genotype had significant differences $(\mathrm{p}<0.05)$ in 6,8 weeks and had extremely significant differences $(\mathrm{p}<0.05)$ in 10 weeks. This study indicated that the polymorphic site could be a genetic marker for growth trait.
\end{abstract}

Key words: Goose, Pit-1, Single Nucleotide Polymorphism (SNP), polymorphism, genetic marker

\section{INTRODUCTION}

Pit-1 is one of the key regulators of gene expression in the anterior pituitary gland. The presence of Pit-1 is an essential and determining factor in the differentiation of the somatotrope, lactotrope and thyrotrope cell lineages (Augustijn et al., 2002).

Pit-1 is a pituitary-specific POU-domain DNA binding factor which binds to and transactivates promoters of Growth Hormone $(\mathrm{GH})$, Prolactin (PRL) and Thyroid-Stimulating Hormone- $\beta$ (TSH $\beta$ ) encoding genes (Ingraham et al., 1988; Bodner et al., 1988; Steinfelder et al., 1992) and the pituitary-specific transcription factor gene (Pit- 1 ) itself in animal anterior pituitary (McCormick et al., 1990; Sornson et al., 1996). The POU domain, named after the proteins POU1F1, OCT-1/OCT-2 and UNC86 which share a common domain, POU1F1 is conserved among species and is responsible for binding to the promoters of target genes (Van As et al., 2000; Weatherly et al., 2001). Pit-1 gene promoter regions is unkonw in livestock and poultry thus single nucleotide polymorphisms analyse mainly in exon and intron, however, many results show that promoter regions bases of mutation, insert and deficiency play a key role in genetic transcription (Liang et al., 2006; Wong et al., 2008; Fan et al., 2010), so the genetic variation of Pit-1 promoter regions has important significance on gene regulation. In the present study, 5-flanking region of Pit-1 gene has been cloned and sequenced using Chinese native geese ( $\mathrm{Zi}$ goose, Taihu goose and Wanxi white goose). The researchers found that polymorphisms clearly existed in the 5-flanking region of Pit-1 gene which might correlate to certain growth traits. The data suggest that these loci might serve as the potential genetic markers for goose breeds.

\section{MATERIALS AND METHODS}

Materials: $\mathrm{Zi}$ goose $(\mathrm{N}=43)$, Wan-xi White Goose $(\mathrm{N}=49)$ and Tai-hu $(\mathrm{N}=102)$ goose was obtained from Gene Pool of National Waterfowl (Taizhou) and reared under the same environment and management. At 10 weeks of age, the blood samples were taken from the wing vein, heparin sodium was used as an anticoagulant. Genomic DNA utilized in PCR amplification was extracted by routing phenol-chloroform method. The rTaq

Corresponding Author: Guo-Hong Chen, College of Animal Science and Technology, Yangzhou University, 225009 Yangzhou, China 
polymerase, dNTP, primer were from Sangon Bioengineering (Shanghai) company and the others were from Baosheng Bioengineering (Dalian) Co. Ltd.

Primers design: Six primers were designed and conducted PCR according to the Pit-1 gene sequence which researcher had cloned, the primer sequence and PCR product size was shown in Table 1.

PCR Amplification and SSCP analysis: PCR reactions were performed in (Eppendorff) according to following program: initial denaturation for $5 \mathrm{~min}$ at $94^{\circ} \mathrm{C}$ and then 34 cycles $\left(94^{\circ} \mathrm{C} 30 \mathrm{sec} ; 51-62^{\circ} \mathrm{C} 30 \mathrm{sec} ; 72^{\circ} \mathrm{C} 50 \mathrm{sec}\right)$ and final extension for $10 \mathrm{~min}$ at $72^{\circ} \mathrm{C}$. The $\mathrm{PCR}$ reaction mix in a total volume of $20 \mu \mathrm{L}$ contained: $10 \times \mathrm{PCR}$ reaction buffer (including $\left.\mathrm{Mg}^{2+}\right), 1.0 \mu \mathrm{L}$ of dNTP mix $(2.5 \mathrm{mM}), 0.2 \mu \mathrm{L}$ of Taq DNA polymerase $\left(5 \mathrm{U}_{\mu} \mathrm{L}^{-1}\right), 0.5 \mu \mathrm{L}$ of forward primer $\left(5 \mathrm{pmol} \mathrm{L}{ }^{-1}\right), 0.5 \mu \mathrm{L}$ of reverse primer $\left(5 \mathrm{pmol} \mathrm{L}^{-1}\right), 1.0 \mu \mathrm{L}$ of DNA template $\left(100 \mathrm{ng} \mu \mathrm{L}^{-1}\right), 14.8 \mu \mathrm{L}$ of $\mathrm{ddH}_{2} \mathrm{O}$. The product of each amplification was analyzed by electrophoresis on $1 \%$ agarose gel $\left(5 \mathrm{~V} \mathrm{~cm}^{-1}\right), 1 \times \mathrm{TBE}$ buffer ( $89 \mathrm{mM}$ Tris, $89 \mathrm{mM}$ boric acid, $2 \mathrm{mMNa}_{2}$ EDTA), using ethidium bromide staining $\left(1 \mu \mathrm{g} \mathrm{mL} L^{-1}\right)$. For SSCP analysis, $2 \mu \mathrm{L}$ PCR products were mixed with $5 \mu \mathrm{L}$ denaturation solution ( $95 \%$ formamide, $0.5 \mathrm{mM}$ EDTA, $0.025 \%$ xylene-cyanole and $0.025 \%$ bromophenol blue), heated for $10 \mathrm{~min}$ at $98^{\circ} \mathrm{C}$ and chilled on ice. Denatured DNA was subjected to PAGE $(10 \%)(200 \times 125 \times 1.00 \mathrm{~mm})$ in $1 \times \mathrm{TBE}$ buffer and constant voltage $(110 \mathrm{~V})$ for $12 \mathrm{~h}$. The gel was stained with $0.1 \%$ silver nitrate. The PCR products from different SSCP genotypes were sub-cloned to T-vector (Promega) and sequenced by Shanghai Sangon Biological Engineering Technology and Service Co., Ltd, Shanghai, China. For the same genotype, three samples from different individuals were sequenced independently at least.

Statistical analysis: All data were analyzed by ANOVA procedure of the statistical software SPSS version 17.0. The association between Pit-1 gene and productive traits of three goose breeds were analyzed by linear model and calculated using the least square method. A fixed model was adopted according to the factors that affect phenotypic traits by using the following equation:

$$
\mathrm{Y}=\mu+\mathrm{B}+\mathrm{G}+\mathrm{G} \times \mathrm{B}+\mathrm{e}
$$

$\mathrm{Y}=$ Trait determination

$\mu=$ The average value of the group

$\mathrm{G}=$ The genotype effect

$\mathrm{G} \times \mathrm{B}=$ Genotype-group interaction effect

$\mathrm{e} \quad=$ Random effect of residual variance

\section{RESULTS AND DISCUSSION}

The PCR Amplification 5' sequence of pit1 gene of goose: Six primers were designed to amplify the 5' sequence of $P i t-1$ gene. The results showed there was specific and clear band for each primer respectively (Fig. 1), the PCR product could be used for PCR-SSCP analysis.

Detection of the goose Pit-1 genetic polymorphism SSCP detection 5' sequence of pit1 gene: PCR-SSCP results showed the genetic polymorphism was detected only at $\mathrm{p} 4$ primer. For $\mathrm{p} 4$ primer, there were tow alleles (named C and T) and 2 genotypes were observed (Fig. 2), defined CCand TT genotype respectively.

Sequencing analysis: DNA sequencing analysis showed there was just one mutation found (c.-930C $>$ T) (Fig. 3), the mutation may increase or decrease MNB1a, Dof2, Dof3, $\mathrm{PBF}$ and $\mathrm{Hb}$ transcription factor binding sites.

Genotypes and allele frequency distribution in different goose group: The genotype and alleles frequency was shown in Table 2. For the P4 locus, the dominant alleles was $\mathrm{C}$ for three goose breeds. It was clear to see from Table 3 , the distributions of the P4 locus were no difference $(\mathrm{p}>0.05)$ among the goose populations.

Least square analysis of the genotype the group and the body weight: In this study, the association of the $\mathrm{GH}$ gene polymorphism with the body weight was revealed

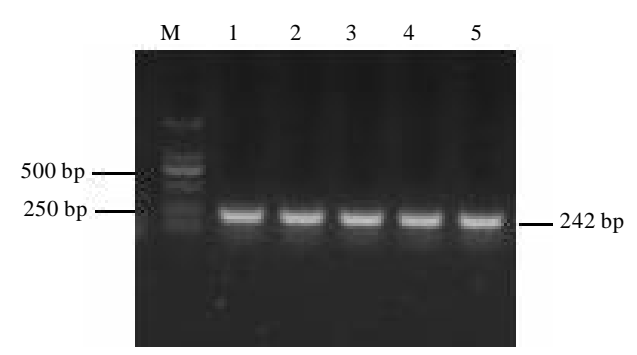

Fig. 1: The PCR products of $\mathrm{p} 4$ primer M Marker (DL2000)

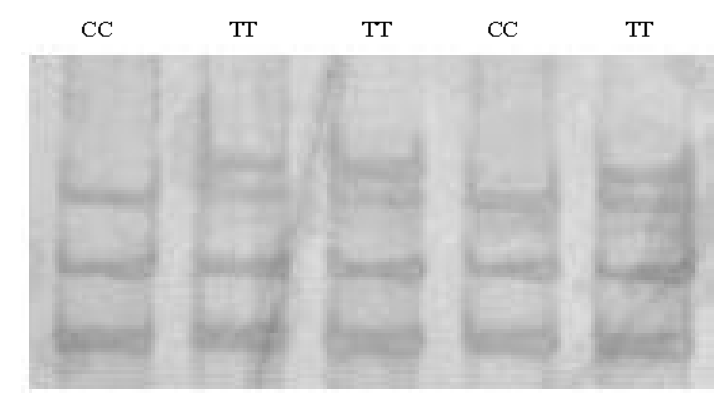

Fig. 2: SSCP analysis of PCR products of the $\mathrm{p} 4$ of pit1 gene 


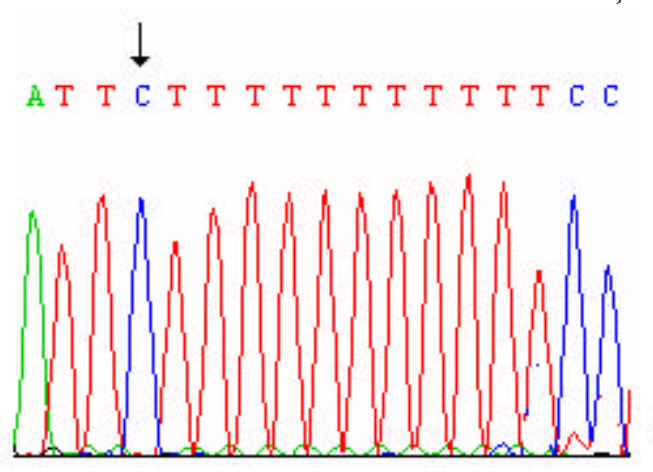

Fig. 3: Sequence of CC and TT genetypes at -930 site

\begin{tabular}{|c|c|c|c|}
\hline Primer & Sequences & $\begin{array}{c}\text { Amplified } \\
\text { length }\end{array}$ & $\begin{array}{l}\text { Ann. } \\
\text { temp }\end{array}$ \\
\hline P1 & F 5'- CCTGGTCGTTGTTCTTCAC -3' & 129 & 53 \\
\hline & R 5'- ATAGAGCCTCCTTCCTTCC -3' & & \\
\hline $\mathrm{P} 2$ & $\begin{array}{l}\text { F 5' CGATAGCAAGACAAATGATG -3' } \\
\text { R 5'- TGTGAAGAACAACGACCAG -3' }\end{array}$ & 255 & 52 \\
\hline P3 & $\begin{array}{l}\text { F 5'- GTTCCAAAGTCATTCTGTT -3' } \\
\text { R 5'- AGTCATCATTTGTCTTGCT -3' }\end{array}$ & 327 & 47 \\
\hline P4 & $\begin{array}{l}\text { F 5'- CTTAAACCAAGAGTATCGT - } 3^{\prime} \\
\text { R 5'- AACAGAATGACTTTGGAAC - } 3^{\prime}\end{array}$ & 242 & 46 \\
\hline P5 & $\begin{array}{l}\text { F 5'- CATTTGGTGGCGGTATCTT -3' } \\
\text { R 5'- GTTGGGTCAGCCCGTAAA-3' }\end{array}$ & 379 & 56 \\
\hline P6 & $\begin{array}{l}\text { F } 5{ }^{\prime} \text {-GTTGGGTCAGCCCGTAAA - } 3^{\prime} \\
\text { R 5'-ATACCGCCACCAAATGAAC - } 3^{\prime}\end{array}$ & 176 & 56 \\
\hline
\end{tabular}

Table 2: Genotypes and allele frequency distribution in different goose groups in $\mathrm{p} 4$ primer

\begin{tabular}{llcl}
\hline Groups & Zi goose (43) & Taihu goose (102) & $\begin{array}{c}\text { Wanxi white } \\
\text { goose (49) }\end{array}$ \\
\hline CC & $0.6047(26)$ & $0.6078(62)$ & $0.6122(30)$ \\
TT & $0.3953(17)$ & $0.3922(40)$ & $0.3878(19)$ \\
CT & $0(0)$ & $0(0)$ & $0(0)$ \\
C & 0.6047 & 0.6078 & 0.6122 \\
T & 0.3953 & 0.3922 & 0.3878 \\
\hline
\end{tabular}

Table 3: $\chi^{2}$-test of genotypes distribution in different goose groups

\begin{tabular}{llcc}
\hline Primer & Groups & Wanxi white goose & Zi goose \\
\hline P4 & Taihu goose & 0.00 & 0.00 \\
& Wanxi white goose & - & 0.01 \\
\hline
\end{tabular}

$\chi_{0.05(1)}^{2}=3.84, \chi_{0.01(1)}^{2}=6.63$

Table 4: Effect of the source of variation on the value of growth trait F-value (Primer P4)

\begin{tabular}{lccccc} 
& & & & & \\
Sourse & 2 weeks & 4 weeks & 6 weeks & 8 weeks & 10 weeks \\
\hline Group & $164.908^{* *}$ & $193.691^{* *}$ & $150.907^{* *}$ & $131.395^{* *}$ & $116.560^{* *}$ \\
Genotype & 0.374 & 2.759 & $9.399^{* *}$ & $12.567^{* *}$ & $21.385^{* *}$ \\
Group- & 0.304 & 0.315 & 0.290 & 0.183 & 0.754 \\
genotype & & & & & \\
\hline${ }^{*} p<0.05, * * p<0.01$ & & & &
\end{tabular}

(Table 4), the result showed that the group effect of the bodyweight was significantly different $(\mathrm{p}<0.01)$ among the group, the genotype effect of that was significantly difference $(p<0.01)$ in $6,8,10$ weeks. The effect of genotype-group interaction was not significantly difference $(\mathrm{p}>0.05)$.

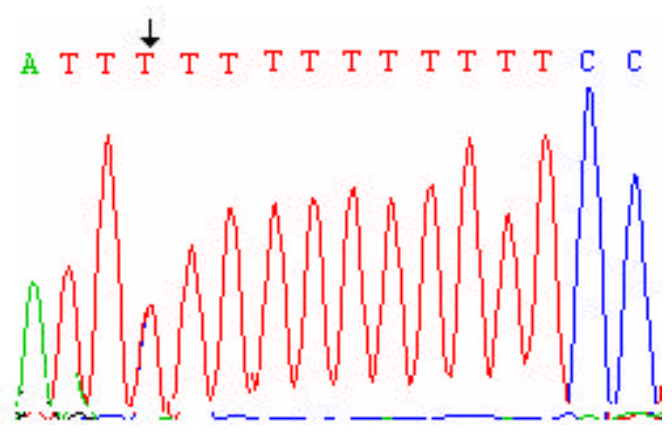

Table 5: Comparison of bodyweight in different groups

\begin{tabular}{lrrr}
\hline Items & Zi goose & Taihu goose & Wanxi white goose \\
\hline 2 weeks & $279.10 \pm 7.760^{\mathrm{a}}$ & $410.44 \pm 7.700^{\mathrm{b}}$ & $491.37 \pm 6.910^{\mathrm{c}}$ \\
4 weeks & $735.51 \pm 15.78^{\mathrm{c}}$ & $1104.00 \pm 18.25^{\mathrm{a}}$ & $1225.22 \pm 15.09^{\mathrm{b}}$ \\
6 weeks & $1210.80 \pm 27.06^{\mathrm{b}}$ & $1843.57 \pm 23.57^{\mathrm{c}}$ & $1905.79 \pm 30.99^{\mathrm{a}}$ \\
8 weeks & $1745.67 \pm 40.82^{\mathrm{a}}$ & $2379.32 \pm 29.54^{\mathrm{b}}$ & $2663.71 \pm 37.21^{\mathrm{c}}$ \\
10 weeks & $2090.35 \pm 39.45^{\mathrm{c}}$ & $2652.35 \pm 32.79^{\mathrm{a}}$ & $3119.29 \pm 55.44^{\mathrm{b}}$ \\
\hline The same superscripts in the same line means not significant difference \\
( $>0.05)$, different superscripts means significant difference $(\mathrm{p}<0.05)$
\end{tabular}

In addition, the body weight of different breeds was analyzed statistically using analysis of variance and compared by way of Duncan in this study (Table 5). The results indicated the body weight of every week of age was significantly difference $(p>0.05)$ in the three goose group and the general trend was Wan-xi white goose $>$ Taihu goose $>\mathrm{Zi}$ goose. That of Wan-xi white goose was the highest and greater than Taihu goose and $\mathrm{Zi}$ goose $(\mathrm{p}<0.01)$. The genotype effect of the body weight at P4 locus was shown in Table 6 using the least squares. In the three goose groups, the general trend of body weight was CC>TT. In WanXi white goose and zi goose groups, there was significant difference $(p<0.05)$ in 6 and 8 weeks, there is an extremely sigrdficant difference $(\mathrm{p}<0.01)$ in 10 weeks but there was no difference $(\mathrm{p}>0.05)$ in 6 weeks. The candidate gene approach is justified when genes previously identified in species of interest or in other species have functions related to the traits of interest (Yu et al., 1995). Due to Pit-1 had played crucial regulatory function and varieties of bioactivities, Pit-1 has been regarded as a key candidate gene for production performance at present

There are indications that variations of $P i t-1$ gene are related to growth, carcass, milk productionand fatty traits in Farm Livestock (Brunsch et al., 2002; Song et al., 2005; Zhao et al., 2004; Jiang et al., 2004; Lan et al., 2007) however, these studies are mainly concentrated on the exons and introns of pitl gene and few promoter polymorphism of pitl gene researchs is reported, Recently, it has been shown that the allele A has a favorable positive effect on growth traits in different genotypes of Pit-1 5' flank region and growth performance 
Table 6: Least square means standard and deviation of different genotypes in primer $\mathrm{P} 4$ for growth trait

\begin{tabular}{|c|c|c|c|c|c|c|}
\hline \multirow{2}{*}{$\begin{array}{l}\text { Group/ } \\
\text { weeks }\end{array}$} & \multicolumn{2}{|c|}{ Wanxi white goose } & \multicolumn{2}{|l|}{ Taihu goose } & \multicolumn{2}{|l|}{$\mathrm{Zi}$ goose } \\
\hline & $\mathrm{CC}$ & TT & $\mathrm{CC}$ & TT & $\mathrm{CC}$ & TT \\
\hline 2 & $491.68 \pm 10.05$ & $490.90 \pm 08.390$ & $410.28 \pm 09.39$ & $410.68 \pm 13.49$ & $285.54 \pm 10.24$ & $267.50 \pm 11.32$ \\
\hline 4 & $1232.10 \pm 19.40$ & $1214.55 \pm 24.200$ & $1116.76 \pm 22.21$ & $1084.53 \pm 31.48$ & $757.21 \pm 19.76$ & $699.76 \pm 24.47$ \\
\hline 6 & $1956.48 \pm 38.24^{*}$ & $1828.42 \pm 48.120^{*}$ & $1872.29 \pm 28.01$ & $1799.05 \pm 41.02$ & $1253.29 \pm 34.11^{*}$ & $1140.82 \pm 40.07^{*}$ \\
\hline 8 & $2731.41 \pm 44.67^{*}$ & $2560.37 \pm 58.430^{*}$ & $2426.84 \pm 37.53^{*}$ & $2305.68 \pm 46.01^{*}$ & $1808.38 \pm 54.42^{*}$ & $1638.71 \pm 52.00^{*}$ \\
\hline$\underline{10}$ & $3234.93 \pm 56.06^{* *}$ & $2936.68 \pm 100.60^{* *}$ & $2715.65 \pm 41.60^{* *}$ & $2554.25 \pm 49.98^{* *}$ & $2175.45 \pm 47.15^{* *}$ & $1945.18 \pm 55.82^{* *}$ \\
\hline
\end{tabular}

in Sujiang pig so Promoter of Pitl polymorphism research also has certain significance. In this study, firstly analysed polymorphisms and investigated the association between polymorphisms and growth traits in the 5' Flank of goose Pit-1 gene, six primers are designed and only $\mathrm{P} 4$ primer was detected to have polymorphisms. The results showed that one SNPs were detected which were C-930T, respectively. Two kinds of genotypes (CC and TT) were detected, genotypes distribution have no significant differences $(p>0.05)$ and the dominant alleles was $C$ for three goose breeds.

The least square on genotypes and groups analysis showed that there were significant differences $(p<0.01)$ on body weight of different weeks in different groups and genotype, however, there were no differences $(p>0.05)$ on body weight of different weeks in genotype-group interaction effect then Comparison of bodyweight in different groups show that the average body weight of wanxi white goose was the largest, the average body weight of taihu goose was larger than zi goose.

Variance analysis on genotype show that the average body weight of CC genotype and TT genotype had significant differences $(\mathrm{p}<0.05)$ in 6,8 weeks and had extremely significant differences $(p<0.05)$ in 10 weeks. This result indicated that the goose with the CC genotype had higher body weight, Therefore this study indicated that the polymorphic site could be a genetic marker for growth trait.

\section{CONCLUSION}

This experiment was conducted to study the Polymorphism on Pit-1 5' flank region in goose. Only one SNPs was found in the sequence of Pit-1 5' flank region and 2 genotypes were detected in 3 goose populations. The least square analysis showed that the goose with the CC genotype had higher body weight, Therefore this study indicated that the polymorphic site could be a genetic marker for growth trait.

\section{ACKNOWLEDGEMENTS}

This study was supported by Mordern Agricultural Industry Technology System Special Fund (nycytx-45-04), National Science and Technology Planning Project
(2006BDA01A09 and 2006BDA14B06) and Provincial Universities Natural Science Basic Research Project (07KJB230138) in Jiangsu, China.

\section{REFERENCES}

Augustijn K.D., D.L. Duval, R. Wechselberger, R. Kaptein and A. Gutierrez-Hartmann, 2002. Structural characterization of the PIT-1/ETS-1 interaction: PIT-1 phosphorylation regulates PIT-1/ETS-1 binding. Proc. Natl. Acad. Sci. USA., 99: 12657-12662.

Bodner, M., J.L. Castrillo, L.E. Theill, T. Deerinck, M. Ellisman and M. Karin, 1988. The pituitary-specific transcription factor GHF-1 is a homeobox-containing protein. Cell, 55: 505-518.

Brunsch, C., I. Sternstein, P. Reinecke and J. Bieniek, 2002. Analysis of associations of PIT1 genotypes with growth, meat quality and carcass composition traits in pigs. J. Applied Genet., 43: 85-91.

Fan, H., D. Liu, X. Qiu, F. Qiao and Q. Wu et al., 2010. A functional polymorphism in the DNA methyltransferase-3A promoter modifies the susceptibility in gastric cancer but not in esophageal carcinoma. BMC Med., 8: 12-12.

Ingraham, H.A., R.P. Chen, H.J. Mangalam, H.P. Elsholtz and S.E. Flynn et al., 1988. A tissue-specific transcription factor containing a homeodomain specifies a pituitary phenotype. Cell, 55: 519-529.

Jiang, R., J. Li, L. Qu, H. Li and N. Yang, 2004. A new single nucleotide polymorphism in the chicken pituitary-specific transcription factor (POU1F1) gene associated with growth rate. Anim. Genet, 35: 344-346.

Lan, X.Y., C.Y. Pan, H. Chen, C.L. Zhang and J.Y. Li et al., 2007. An AluI PCR-RFLP detecting a silent allele at the goat POU1F1 locus and its association with production traits. Small Rumin. Res., 73: 8-12.

Liang, Y., J. Cui, G. Yang, F.C.C. Leung and X. Zhang, 2006. Polymorphisms of 5 ' flanking region of chicken prolactin gene. Domestic Anim. Endocrinol., 30: 1-16. McCormick, A., H.L. Brady, E. Theill and M. Karin, 1990. Regulation of the pituitary-specific homeobox gene GHF1 by cell autonomous and environmental cues. Nature, 345: 829-832. 
Song, C., B. Gao, Y. Teng, X. Wang and Z. Wang et al., 2005. MspI polymorphisms in the 3rd intron of the swine POU1F1 gene and their associations with growth performance. J. Applied Genet., 46: 285-289.

Sornson, M.W., W. Wu, J.S. Dasen, S.E. Flynn and D.J. Norman et al., 1996. Pituitary lineage determination by the Prophet of Pit-1 homeodomain factor defective in ames dwarfism. Nature, 384: 327-333.

Steinfelder, H.J., S. Radovick, M.A. Mroczynski, P. Hauser, J.H. McClaskey, B.D. Weintraub and F.E. Wondisford, 1992. Role of a pituitary-specific transcription factor (Pit-1/GHF-1) or a closely related protein in cAMP regulation of human thyrotropin-b subunit gene expression. J. Clin. Invest., 89: 409-419.

Van As, P., N. Buys, O.M. Onagbesan and E. Decuypere, 2000. Complementary DNA cloning and ontogenic expression of pituitary-specific transcription factor of chickens (Gallus domesticus) from the pituitary gland. General Comparative Endocrinol., 120: 127-136.
Weatherly K.L., R. Ramesh, H. Strange, K.L. Waite, B. Storrie, J.A. Proudman E.A. Wong, 2001. The turkey transcription factor Pit- $1 / \mathrm{GHF}-1$ can activate the turkey prolactin and growth hormone gene promoters in vitro but is not detectable in lactotrophs in vivo. General Comparative Endocrinol., 123: 244-253.

Wong, H.L., W.P. Koh, N.M Probst-Hensch, D. van den Berg, M.C Yu and S.A Ingles, 2008. Insulin-like growth factor-1 promoter polymorphisms and colorectal cancer: A functional genomics approach. Gut., 57: 1090-1096.

Yu, T.P., C.K. Tuggle, C.B. Schmitz and M.F. Rothschild, 1995. Association of PIT1 polymorphisms with growth and carcass traits in pigs. J. Anim. Sci., 73: $1282-1288$.

Zhao, Q., M.E. Davis and H.C. Hines, 2004. Associations of polymorphisms in the Pit-1 gene with growth and carcass traits in Angus beef cattle. J. Anim. Sci., 82: $2229-2233$. 